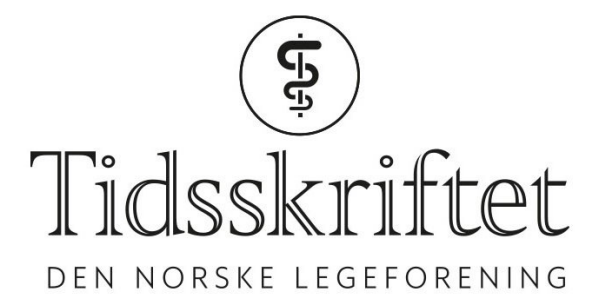

\title{
Viktige aspekter i behandlingen for ALS-pasienter
}

KOMMENTAR

\section{NILS MAGER ØY}

E-post: nils.mageroey@helse-bergen.no Nils Magerøy er phd., spesialist i allmennmedisin og overlege ved Bjørgvin DPS, Haukeland universitetssjukehus. Var overlege og leder for det som den gang het Sunniva Hospice, Haraldsplass sykehus, i perioden 1993-1999.

Forfatteren oppgir ingen interessekonflikter.

Morten Andreas Horn trekker prisverdig fram at vi som leger har en viktig jobb å gjøre for pasienter med amyotrofisk lateral sklerose (ALS) (1). Han viser til at mange media-oppslag er knyttet til det negative rundt sykdommen herunder ønsker om dødshjelp. Videre viser han til de mange gode innsatser som kan gjøres for disse pasientene for at de skal få hjelp til å gjennomgå dødelig sykdom med livskvaliteten og verdigheten i behold. Basert på erfaring fra arbeid med ALS pasienter er det likevel to behandlingsaspekter som jeg synes det er grunn til å framheve og et tredje moment som det i den offentlige debatten er viktig å være klar over (2).

1. Pasienten bør sette agenda for hva de trenger og ønsker hjelp til. Dermed vil de i større grad oppleve de å ha kontroll i situasjonen.

2. Hjelpemidlene må komme før funksjonsfallet. Det vil si at krykker, rullestol, hevesenkeseng, forflytningshjelpemidler, øyepeketavle, pustemaskin og så videre må være på plass den dagen pasienten trenger disse og andre hjelpemidler.

3. Det er pasienten som har råderetten over når en eventuell pustemaskin skal slås av eller ikke settes i gang (3). I en slik situasjon plikter vi som leger å gi lindrende behandling som gjør at pasienten ikke skal slite med å oppleve åndenød i den siste fasen av livet. Det kan bety at livet blir noen timer kortere, men da er ikke hensikten å ta livet av pasienten, men lindre slik at pasientens $\mathrm{d} ø \mathrm{~d}$ blir fredeligst mulig.

Det er viktig å være klar over at det finnes sentere med betydelig kompetanse som kan komme ALS-pasienter til nytte. Sunniva senter ved Haraldsplass diakonale sykehus i Bergen har til enhver tid rundt 15 pasienter med ALS (opplyst av professor Rosland juni 2019). Det er i en tidlig fase av dette arbeidet undertegnede møtte mennesker med ALS. For de fleste av disse var livet svært meningsfullt også i tiden med sykdommen. Det hendte mer enn en gang at pasienter vi fulgte uttalte «jeg er frisk jeg» selv om han eller hun kom kjørende i rullestol. 
LITTERATUR:

1. Horn MA. Kan vi være til nytte for ALS-pasientene? Tidsskr Nor Legeforen 2019; 139. doi: 10.4045/tidsskr.19.0425. [PubMed][CrossRef]

2. Magerøy N. Åpent brev til Knut Bjarkeid. Vårt Land 16.6.2019.

http://www.verdidebatt.no/innlegg/11751995-apent-brev-til-knut-bjarkeid Lest 16.6.2019.

3. Husabø EJ. Rett til sjølvvalt livsavslutning? Oslo: Ad Notam Gyldendal, 1994.

Publisert: 23. september 2019. Tidsskr Nor Legeforen. DOI:10.4045/tidsskr.19.0552

(C) Tidsskrift for Den norske legeforening 2020. Lastet ned fra tidsskriftet.no 